\title{
What should the young be told?
}

\section{Britain's planned revolution of school education is potentially both rewarding and disastrous. The government had better go carefully.}

THE post-election British government has embarked on a remarkable task - the design and enforcement of a national curriculum for secondary schools. Bucking its own trend of letting things find their own level, preferably a market-level, it plans in the autumn to decree that the education of the young should be built around a small set of examinable bodies of knowledge. The proposals will certainly become reality; too many British parents are vaguely dissatisfied with the education of their children for it to be otherwise. The danger is that the British government, in forcing through the House of Commons 500 clauses, each of which might occupy a parliamentary session, will do a disservice to its own people and set a bad example for other governments.

There is nothing wrong with the notion of a core curriculum indeed, the opposite is true. Plainly it would assist the mobility of families from one place to another if there were some general understanding of what young people should be taught at school. There may also be something in the British government's claim last week that a national curriculum would enable parents more accurately to tell to which schools they should send their children, although that contention will occupy much of the parliamentary time between now and the next-but-one parliamentary session, if only because of the suspicion that parental choice is a euphemism for privately financed education. Certainly it would help if young people themselves had some general idea of the objectives of school education. Is it cultural, or for helping to find a job? (Or does the second follow from the first?) The upbeat message in the government's own justification of its intended course of action is that too many young people's expectations of themselves are at present deflated by their teachers' diminished expectations of young people.

The snags, as always, come in the fine print. On the face of things, the proposals in the British government's consultative document are reasonable enough: let there be "maths" (for mathematics), English and science at the core of the core; beyond that will follow "a modern foreign language, technology, history, geography, art, music and physical education". As in all British schools since 1944, there will also be a modicum of religious education. An enchanting block of fine print dealing with the teaching of the Welsh language carefully avoids the issue of whether this minority language will be an acceptable alternative to English. But, for the generality of British students, there will be test of attainment in the core-core subjects every few years (at ages seven, eleven, fourteen and sixteen). The intention is that the results of these attainment tests should be public knowledge so that parents may choose between schools and students be catered for appropriately.

\section{Danger}

Superficially, there is nothing wrong with what is planned, but there is a danger that the sum of human knowledge has been so whittled down, in the British government's proposals, that when used not merely as a test of individual students' attainments, but of those of schools, it will be a self-defeating goal. Take "maths", for example. If a school knows that its public reputation will hang on its overall attainment at pre-determnined aptitude tests, will it ever make sense for it to allow teachers occasionally to teach Latin to odd-ball students when they might be more gainfully employed drilling young people in the mysteries of proportionality? The risk that the core curriculum will be homogenized pap needs to be considered.

There is also a problemn about science, trendily part of the "core of the core" because of the British government's touching (but correct) devotion to the belief that science will breed technology that will breed prosperity. The fallacy in the inference that everybody should be taught science from the year dot is most simply exposed by the simple question of how many captains of industry admit to having been persuaded that the future would be both more technological and more full of opportunity because of what they had been taught of science at their primary schools. The plain truth is that there is no known successful way of giving very young people a sense of science and technology, but only a smattering of a sense of what they may be about. Some very young people with intellectual energy to spare find out, usually by accidents that clever teachers devise at later ages. In Britain in particular, there is a depressing record of how too much formal teaching of science (and even mathematics) has driven bright young people in the opposite direction. Can it be wise to engineer a revolution in the British educational system when a third of the assessable content of the curriculum is unteachable between the ages of, say, 5 and 12 ? Would not the same young people be better occupied learning French, or German, or even Welsh?

\section{Dispute}

It would be a less taxing conundrum if there were different teachers. Conventional wisdom has it that British schools have gone to the dogs because the teachers are no good, but that is only a reflection of the way in which British teachers have appeared recalcitrant employees of the public service in the past three years of dispute with their employers (essentially the central government) over pay. The government has won that battle, but may have lost the war by demoralizing the people on whom it must depend, not merely to make the core curriculum a reality, but to enrich the prescription now on offer with the ingredients that will allow young people leaving British schools to believe themselves to have been educated for the modern world. To put things right and to make its core curriculum a success, the government will have to pay out more than the extra $£ 3,000$ million a year it found on the eve of the general election to settle its pay dispute with the teachers to give the teachers the belief that their schools are again properly equipped.

The British government's problem, which falls to Mr Kenneth Baker, its Secretary of State for Education and Science, is that of turning its largely dedicated teaching force into people who believe their students have a brighter future. The fly in that ointment is that the British government appears to be heading in two directions at the same time - towards a national system of publicly maintained schools in which a single curriculum will be supreme and towards an enlarged system of private education to which fewer restraints (except those of parental approbation) will apply. Can that, politically, make sense? 